$[$ ノート]

\title{
動的荷重センサーを用いたアスファルト混合物の 荷重分散特性の検討
}

\author{
笠原 彰彦* ${ }^{\dagger 1)}$ ，天野 隆明，森吉 昭博 \\ 北海道大学工学部, 060-0813 札幌市北区北 13 条西 8 丁目
}

(平成 9 年 9 月 8 日受理)

\begin{abstract}
本研究は，載荷走行時のアスファルト混合物層下面における鉛直応力の相対的な分布を動的荷重センサーを用いた 室内走行実験より求め, 荷重や混合物温度の変化が荷重分散の特性に与える影響を検討した。この結果と弾性および 粘弾性理論による応力解析結果との比較も行った。

実験の結果，実際の荷重分散は弾性および粘弾性理論による解析結果よりも広範囲に及ぶこと，本実験で対象とし た範囲での混合物温度の变化は荷重の分散特性に大きく影響を及ほすが，荷重の大きさが同特性に及ほす影響は小さ いことなどを明らかにした。
\end{abstract}

\section{1. 緒言}

高温時や低速での載荷時にアスファルト舗装で生じるわだち 掘れは，その変形形態の違いから空げき率の減少による圧密現 象と混合物の水平方向への移動を伴った，いわゆる流動現象と に大別される1。こうした変形形態の違いやその変形量は載荷 時のアスファルト混合物内部での応力状態による影響が大き い。

載荷時のアスファルト混合物内部の応力状態は理論解析によ る結果を用いるのが一般的であり，わだち掘れの予測などに関 する種々の研究 2) 4) で適用されているが, 理論解析によって わだち掘れを適切に説明できるまでには至っていない。一方， 混合物内部の応力を実際に測定した例は少なく，野外の道路に 近い動的な載荷条件下での実測に関しては測定が非常に難しい ことからこれまで行われていない。したがって，載荷時のアス ファルト混合物内部での応力状態は同混合物の変形において極 めて重要な条件でありながら，未だに明らかとされていないの が現状である。

本研究では，動的荷重に対して応答するセンサー（以下，動 的荷重センサー）を用いた室内走行試験をアスファルト混合物 の弾性および塑性領域の範囲で行い，載荷走行時の混合物層下 面における鉛直応力の相対的な分布より荷重や混合物温度の変 化が荷重分散の特性に及ほす影響を検討した。さらに，弾性領 域における結果と弾性㧍よび粘弾性理論を用いた応力解析結果 との比較も行い, 動的な載荷状態における荷重分散との違いに ついて検討した。

\section{2. 実 験 概 要}

\section{1. 動的荷重センサーの特徵}

動的荷重センサーの形状は細い線状 $(3 \mathrm{~mm} \phi)$ で，フレキシ

* 連絡先

†1) (現住所) 日本鋪道(株) 北方技術研究所, 061-1405 北海 道恵庭市戸磯 76-21
Table 1 Specifications of Sensor

\begin{tabular}{lrc} 
Quality of sheath & Copper \\
Diameter of sheath & {$[\mathrm{mm}]$} & 3 (dia.) \\
Length r & {$[\mathrm{mm}]$} & 300 \\
Sensitivity $\quad\left[\mu \cdot \mathrm{V} \cdot \mathrm{N}^{-1} \cdot \mathrm{m}^{2}\right]$ & 1 \\
Range of temp. & {$\left[{ }^{\circ} \mathrm{C}\right]$} & $-70-100$ \\
\hline
\end{tabular}

ブルなため湾曲した場合でも使用可能である。また, 当該セン サーの断面は同軸上の銅製の外郭と芯 (しん) 線の間に分極され た圧電性のセラミック粉末が充てんされた構造となっている。 当該センサーの主な仕様を Table 1 に示す。

動的荷重センサーは次のような特徴を有する。当該センサー は, 加圧されることによって芯線と外郭間で外力に比例した電 圧が生じ，動的な荷重に対してのみ応答する。また，その電圧 は同一荷重条件でも載荷速度の違いによって異なり，七ラミッ ク粉末の電気的な特性上から温度条件の違いによっても若干変 化するとされている。

当該センサーは欧州において交通量や軸重の検出など, 交通 特性の調査で使用実績5) を有しているが，アスファルト混合物 内部の応力分布の測定に関しては適用実績がないため, 最初に 荷重や載荷速度, 温度の变化に対する校正を行い, 本研究への 適用について検討した。

\section{2. 動的荷重センサーの校正方法}

動的荷重センサーの校正は, 極めて平滑な鋼版上にテープで 固定したセンサーにホイールトラッキング試験機の車輪中央部 を直接載荷し, センサー延長方向に走行した際の電圧を各種条 件で測定した。

走行条件は, 荷重 $(20,100,412,510,637 \mathrm{~N}$ の 5 種類), 走行速度 (20，42，60，80 回/分の 4 種類）, 温度 (25, 40, $60^{\circ} \mathrm{C}$ の 3 種類）を適宜組み合わせた 22 種類とし，3 本のセン サーについて校正を行った。当該センサーで生じた電圧は増幅 した後，デジタルレコーダーで記録した。なお，デジタルレコ ーダーによる記録間隔は以下全て $20 \mathrm{~Hz} て ゙$ 行った。 
Table 2 Gradation of Mixture

\begin{tabular}{cc}
\hline Sieve size [mm] & Weight percent yield [\%] \\
\hline 4.75 & 100 \\
2.36 & 85.6 \\
0.6 & 54.9 \\
0.3 & 30.9 \\
0.15 & 8.8 \\
0.075 & 4.9 \\
\hline Asphalt content [\%] & 6.8 \\
\hline
\end{tabular}

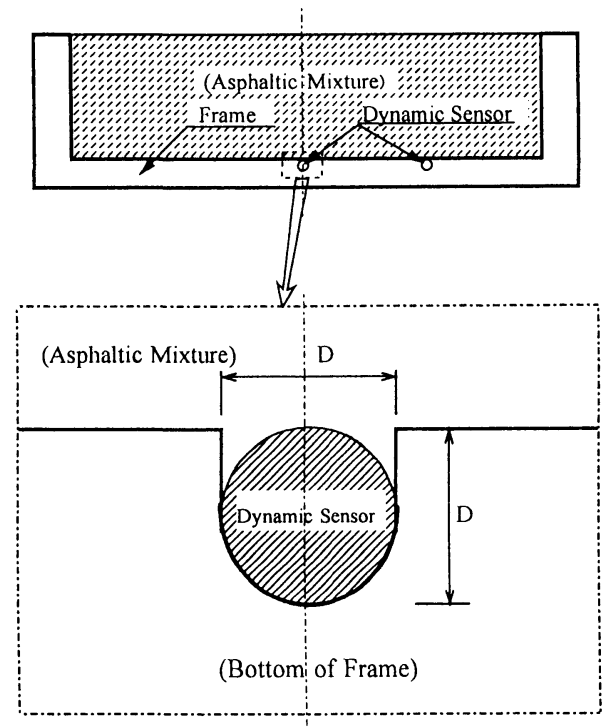

$D$ : Diameter of dynamic sensor.

Fig. 1 Setting of Sensors

\section{3. アスファルト混合物の配合}

試験に用いるアスファルト混合物は，供試体内部の均一性を できるだけ高めるため, 粗骨材を使用しないアスファルトモル タルを選定した。また, アスファルトは舗装用ストレートアス

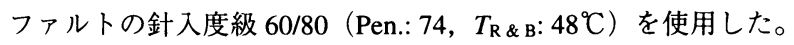
アスファルトモルタルの配合を Table 2 に示す。

\section{4. 供試体の作成方法}

供試体の作成は, センサーを固定したホイールトラッキング 試験の供試体型卆に所定量のアスファルトモルタルを入れ，ロ ーラーコンパクターにより転圧（線圧: $177 \mathrm{~N} / \mathrm{cm}$, 転圧回数: 24 回）した。アスファルトモルタルの混合および転圧温度は アスファルトの粘度がそれぞれ 2 ポアズ， 30 ポアズとなる温 度としており，これらは極めて一般的な作成条件である。

動的荷重センサーの設置状況を Fig. 1 に示す。動的荷重セ ンサーの設置位置は, 当該センサーの断面と同じ形状の溝を走 行方向に設けた供試体型染の底面とした。センサーに鉛直およ び水平応力が同時に加わると, センサーの応答から直接これら を判別することが難しいため, 今回の実験では鉛直応力のみに 着目することとし, 型枠底面に設けた溝の深さはセンサーに加 わる水平㐫力が極力小さくなるようにセンサー径と同一とし た。また，センサーの水平方向の設置位置は供試体中央と中央

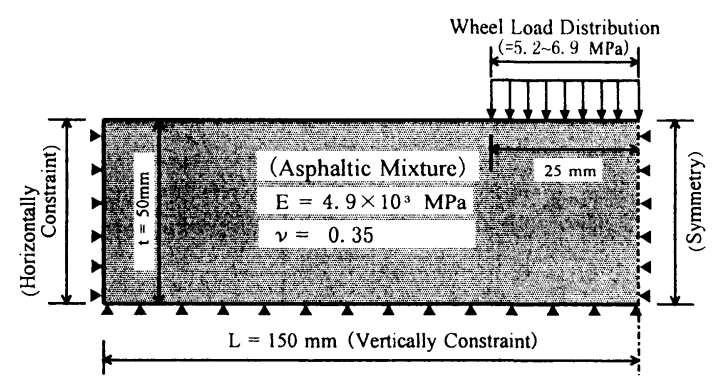

E: Elastic modulus, v: Poisson's raito. FEM indicates elastic and viscoelastic analysis using finite element method.

Fig. 2 Analytic Model of FEM

から $7.5 \mathrm{~cm}$ 離れた位置の 2 種類を設けた。

\section{5. 践荷走行実験の方法}

載荷走行試験では，前述の供試体を用いて，各種条件で当該 センサーの延長方向に載荷走行した際のセンサー電圧を測定し た。アスファルト混合物内部の応力分布は, 走行位置を当該セ ンサーの延長方向と平行に移動することにより評価した。

車輪の走行位置はセンサー直上, これより $3.75,7.5,11.25$, $15 \mathrm{~cm}$ 離れた位置の 5 点とし, センサーの設置位置と適宜組み 合わせた。走行時の各種条件は, 走行速度を全て一定 $(42$ 回／分）とし, 載荷荷重を 412, 510, $637 \mathrm{~N}$ の 3 種類, 混合物 温度を $25,40,60^{\circ} \mathrm{C}$ の 3 種類としてこれらの条件を適宜組み 合わせた。なお，それぞれの条件における走行時間は全て 30 秒とし，各条件とも同一の供試体を使用した。

\section{6. 弾性および粘弾性理論によるアスファルト混合物内部 の応力解析方法}

弾性および粘弾性理論(6)にるアスファルト混合物内部の応 力解析は有限要素法により行った(以下, 有限要素解析と称す)。 解析モデルは載荷走行時の断面を Fig. 2 に示すように模式化 し, 2 次元 4 節点の軸対象要素モデルを設定した。載荷荷重は 等分布荷重とし，その大きさおよび載荷範囲は実測值を用いた。 拘束条件は型枠側面および供試体中央の対象面を水平方向での 固定とし，型枠底面は鉛直方向での固定とした。

\section{3. 結果および考察}

\section{1. 校正時の各種条件が動的荷重センサーの応答特性に及 ぼす影響}

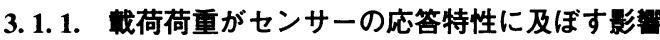

同一センサーで載荷荷重だけが異なる場合の車輪の往復走行 による各動的荷重センサーの電圧変化の一例を Fig. 3 に示す。 同図における電圧変化には車輪の走行周期と一致した周期性が 認められ，その波形は周期毎で比較的安定している。ホイール トラッキング試験機の車輪の速度変化は試験機の構造上, 往復 走行に対して周期性のある波形となることや載荷荷重が異なる 場合でも, 車輪の走行周期に対する依存性は変わらないことか ら同図の電圧変化は主に車輪の往復走行における速度変化に依 存していると推察される。

図中に示した各周期における測定電圧の最大ピーク值 (以下, ピーク電圧と称す) の平均をもとに, 載荷荷重とピーク電圧と 


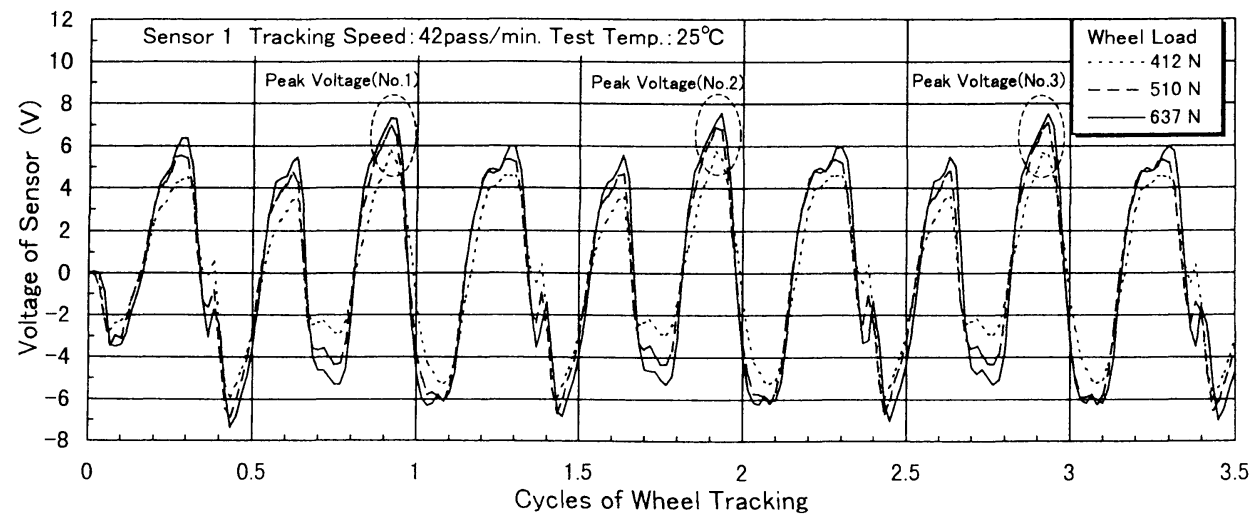

Fig. 3 Voltage of Sensor under Various Wheel Loads (at Calibration)

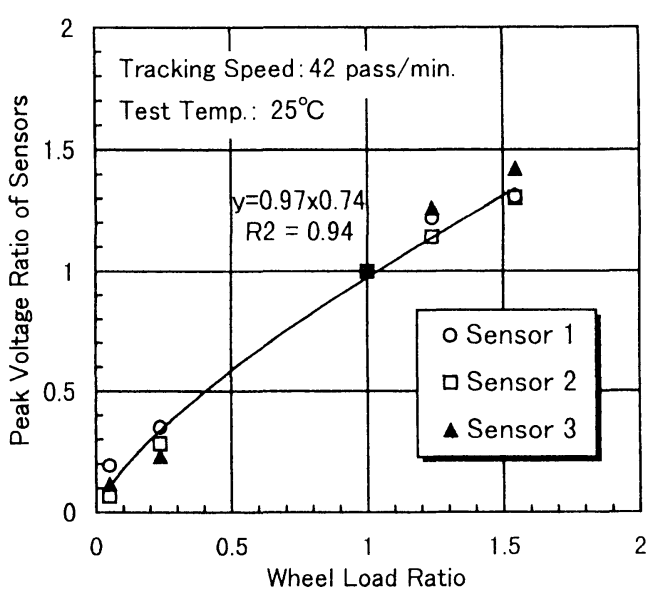

Wheel load ratios with reference to $412(\mathrm{~N})$. Peak voltage ratios with reference to maximum peak voltage of wheel load $412(\mathrm{~N})$.

Fig. 4 Relationships between Wheel Load Ratio and Peak Voltage Ratio of Sensors (at Calibration)

の関係を載荷荷重 $412 \mathrm{~N}$ の場合を基準としたそれぞれの増加割 合により示した結果をFig. 4 に示す。同図によると，載荷荷 重の增加割合に対するピーク電圧の増加割合はセンサーが異な る場合でも大きな差はみられず，しかも両者の間には良い相関 関係か認められる。これは，載荷荷重の增加に対するピーク電 圧の增加の関係がセンサーの構造的仕棣に起因するものであ り，載荷荷重に対する基本的な特性はセンサー間で異ならない ためと考えられる。したがって，動的荷重センサーの応答特性 としてピーク電圧は載荷荷重に大きく依存していると判断さ れ，走行速度が同一であれば同電圧に着目することにより当該 センサーに加わる荷重を推測することが可能である。

\subsection{2. 走行速度がセンサーの応答特性に及ぼす影響}

同一七ンサーで走行速度だけが異なる場合, ピークの生じる 位置など, 波形の特徴は走行速度に応じて若干異なるものの， 測定電圧の変化には周期性が認められた。

走行速度とピーク電圧の増加割合との関係を走行速度 42 回／分を基準として示した際の一例を Fig. 5 に示す。これに よると走行速度の増加に対するピーク電圧の増加割合は各セン

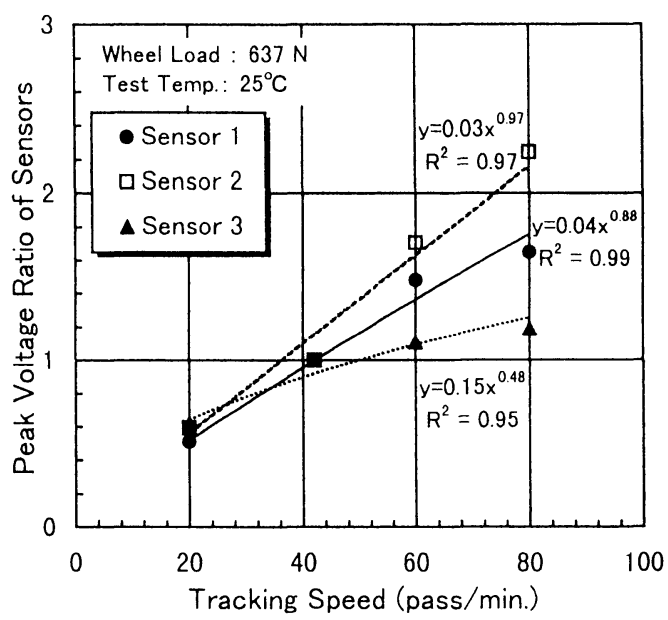

Peak voltage ratios with reference to maximum peak voltage of tracking speed (42 pass/min).

Fig. 5 Relationships between Tracking Speed and Peak Voltage Ratio of Sensors (at Calibration)

サー間で応答特性の違いにより異なるが，いずれのセンサーで も両者の間には良い相関が認められ, 回帰曲線は各センサーと も載荷荷重が異なった場合でも変わらないことが確認できた。 したがって，ピーク電圧は走行速度にも依存するが，同一セン サーであれば走行速度が異なる場合でも Fig. 4 に示した載荷 荷重とピーク電圧の相関関係が得られることから, 走行速度が 異なる場合でもピーク電圧から載荷荷重を求めることが可能で ある。

\section{1.3. 試験温度がセンサーの応答特性に及ぼす影響}

試験温度が異なる場合の載荷荷重とピーク電圧の平均との関 係を求めた結果では, 試験温度が異なる場合でも両者の関係に 大きな差は認められなかった。したがって, 本実験で対象とし た試験温度の範囲では，ピーク電圧に対して試験温度が及ほす 影響は小さいと考えられる。

以上の校正結果から, 載荷荷重や走行速度, 試験温度が変化 した際でも動的荷重センサーの測定電圧の変化は走行周期と一 致した周期性があり，しかも載荷荷重とピーク電圧との間には 


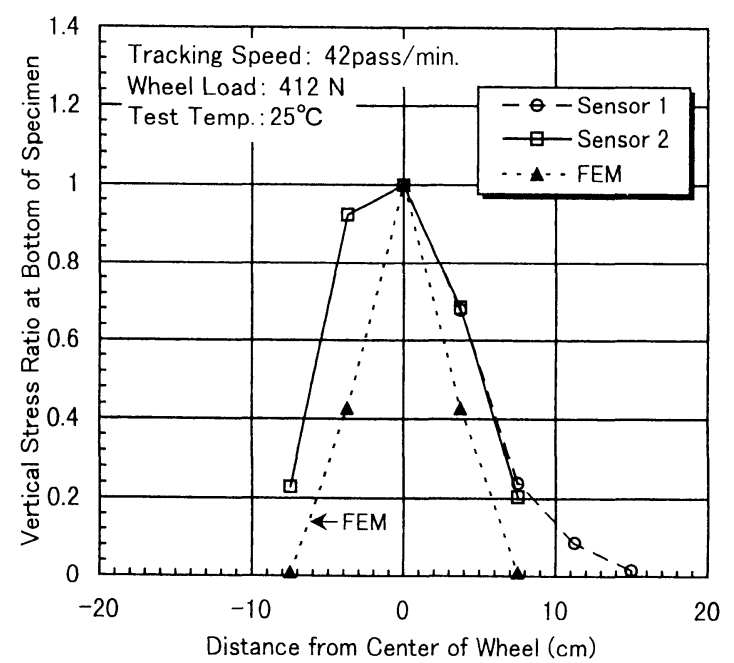

Vertical stress ratios were estimated at maximum peak voltage of sensors and FEM. FEM indicates elastic and viscoelastic analysis using finite element method. Vertical stress ratios with reference to vertical stress just under wheel load.

Fig. 6 Distributions of Vertical Stress Ratio at Bottom of Specimen

良い相関関係が認められた。すなわち，載荷走行時の動的な外 力に対する当該センサーの応答は安定しており，かつ外力の変 化に対して規則性を有することが確認できた。したがって，当 該センサーは載荷走行時におけるアスファルト混合物内部の応 力分布の測定に適用可能と判断される。

今回の校正は外力の因子として荷重を用いており，この結果 による回帰式から混合物内部の応力を直接求めることは難し い。このため，アスファルト混合物内部の鉛直応力の分布は， センサー直上の載荷位置におけるピーク電圧を基準（1とする） とした各位置のピーク電圧の比 (以下, ピーク電圧比と称す) から求めた応力比により相対的に評価することが望ましい。た だし，応力比を求める際のピーク電圧はそれぞれの平均值を用 いた。

\section{2. 動的載荷時のアスファルト混合物の荷重分散と載荷条 件が同特性に及ぼす影響}

\subsection{1. 供試体底面における鉛直応力比の分布}

ピーク電圧比から求めた供試体底面における鉛直応力比の分 布の一例を有限要素解析により求めた各位置の鉛直応力比とと もにFig. 6 に示す。なお，有限要素解析において弾性および 粘弾性理論による解析結果に大きな違いは認められなかった。

同図においてピーク電圧比による鉛直応力比の分布はいずれ もセンサー直上が最も大きく，七ンサーから離れるに従い減少 する。この傾向は有限要素解析結果でも同様であるが, ピーク 電圧比による鉛直応力比は載荷中心より $7.5 \mathrm{~cm}$ 離れた位置で も載荷中心の $20 \%$ 程度あり, 有限要素解析の結果よりもかな り大きい。この結果は実際の荷重分散が有限要素解析の場合よ りも広範囲に及んでいることを示しており，供用中の道路にお いて交通荷重の影響が及ばないと考えられている車輪軌跡の中 間部でも，アスファルト混合物の密度が供用とともに徐々に増

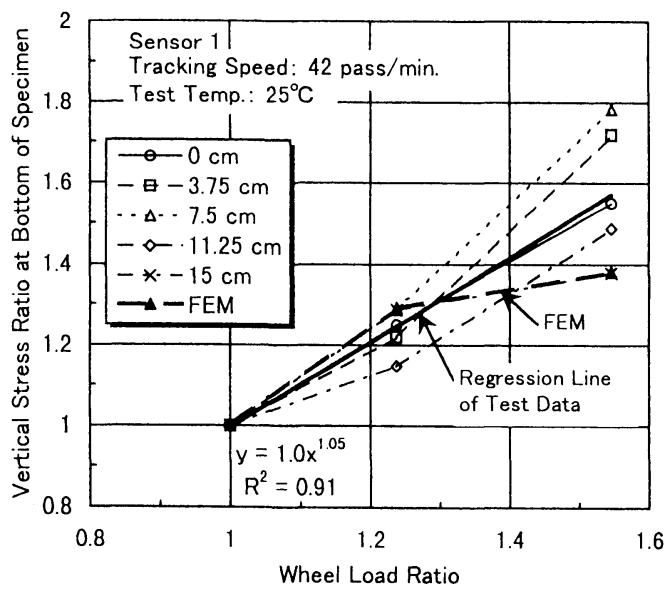

Wheel load ratios with reference to $412(\mathrm{~N})$. Vertical stress ratios were estimated at maximum peak voltage of sensor and FEM. FEM indicates elastic and viscoelastic analysis using finite element method.

Fig. 7 Relationships between Wheel Load Ratio and Vertical Stress Ratio at Bottom of Specimen on each Position

加するのは，実際の道路においても荷重分散が予想よりも広範 囲に及んでいるためと考察される。

\section{2. 2. 载荷荷重が異なることによる荷重分散特性の变化}

載荷荷重と同応力比との関係を載荷荷重 $412 \mathrm{~N}$ の場合を基準 としたそれぞれの増加割合で示したものを各載荷位置毎に Fig. 7 に示す。なお，同図には有限要素解析の結果から求めたもの も併せて示した。これによると，載荷荷重の増加に対する同応 力比の増加割合は各位置とも大きな差はみられず，全ての測定 デー夕を対象とした場合の回帰式からは両者が比例に近い関係 にあると判断される。換言すると載荷荷重が異なる場合でもピ 一ク電圧比による鉛直応力比の分布には大きな差がなく，荷重 の分散特性はあまり変化しないことを示している。また，有限 要素解析による結果との比較では, 本実験の荷重範囲内では両 者に極端な差は認められないが，荷重の増大により差が生じる 傾向がみられることから，本実験の荷重範囲に相当する輪荷重 以上では実際の荷重分散は理論解析結果と異なることが予想さ れる。

3. 2.3. 混合物温度が異なることによる荷重分散特性の変化

混合物温度 $25^{\circ} \mathrm{C}$ のピーク電圧比を基準として求めた供試体 底面における鉛直応力比の分布を各温度毎に Fig. 8 に示す。 これによると載荷中心から $3.75 \mathrm{~cm}$ 離れた位置までの載荷領域 近傍では, 混合物温度の上昇とともに鉛直応力比は増加するが, $7.5 \mathrm{~cm}$ 以上離れた位置では減少する傾向にあり, 同応力比の分 布が混合物温度の上昇とともに応力が載荷領域近傍に集中する ことを示している。したがって，本実験条件内における混合物 温度は荷重の分散特性に大きく影響を及ほす因子と判断され る。

また，混合物温度の上昇に伴う載荷領域近傍での鉛直応力比 の増加を載荷荷重の増加による影響と本実験条件内で比較した 場合, 混合物温度が $25^{\circ} \mathrm{C}$ から 2.4 倍の $60^{\circ} \mathrm{C}$ に上昇した際の鉛 直応力比は，載荷中心およびこれょり $3.75 \mathrm{~cm}$ 離れた位置で 


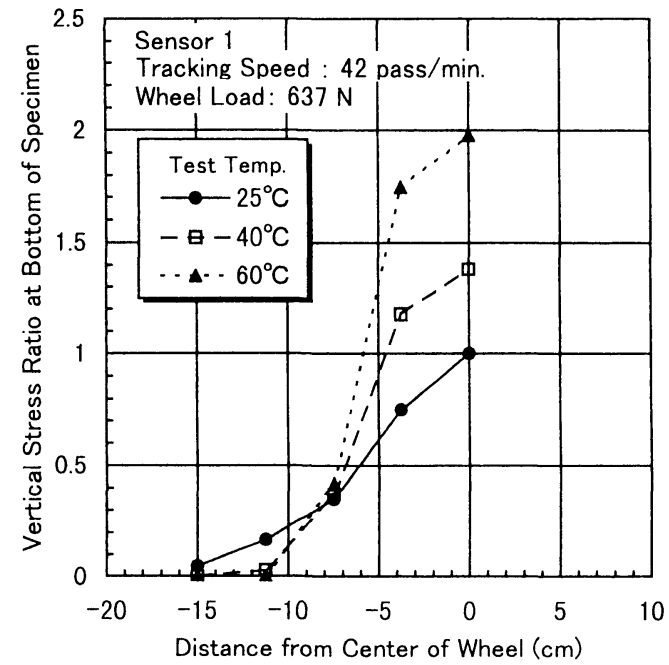

Vertical stress ratios were estimated by maximum peak voltage of sensor. Vertical stress ratios referred to vertical stress just under wheel load, at $25^{\circ} \mathrm{C}$.

Fig. 8 Distributions of Vertical Stress Ratio at Bottom of Specimen at Various Test Temperatures

$25^{\circ} \mathrm{C}$ の 2 2.3 倍と, 温度の増加にほほ比例して増加しており, 載荷荷重の増加による鉛直応力比の増加と同様な傾向にあると 考えられる。したがって，圧密現象と密接な関係にある載荷近 傍の鉛直応力の増加に対して両因子が与える影響はほほ対応し ていると考えられる。

\section{4. 結言}

1）載荷走行時のアスファルト混合物内部における鉛直応力の
相対的な分布は本実験で使用した動的荷重センサーによっ て 測定可能である。

2）載荷走行時のアスファルト混合物内部の鉛直応力比の分布 は載荷中心から $7.5 \mathrm{~cm}$ 離れた位置でも載荷中心の $20 \%$ 程 度であり, 荷重は弾性および粘弾性理論解析よりも広い範 囲に分散している。

3）本実験条件において混合物温度は荷重の分散特性に著しい 影響を及ほし，温度上昇により鉛直応力の集中が生じるが, 載荷荷重の大きさは同特性に大きく影響しない。

4）本実験条件において混合物温度の上昇による載荷近傍での 鉛直応力比の増加は載荷荷重の増加によるものとほほ対応 している。

\section{謝 辞}

本研究を遂行するにあたり，井上 忠氏（五洋建設(株)）、 渡辺貴裕氏（北海道大学大学院）の協力を得た。ここに感謝の 意を表します。

\section{References}

1) Kasahara, A., Amano, T., Tokumitsu, K., Moriyoshi, A., Sekiyu Gakkaishi, 40, (1), 39 (1997).

2) Hicks, R. G., Finn, F. N., Proc. AAPT, 43, 1 (1974).

3) Gerlach, A., Loizos, A., Lucke, H., Proc. The 6th International Conference on Structural Design of Asphalt Pavements, 72 (1987).

4) Eckmann, B., Proc. The 6th International Conference on Structural Design of Asphalt Pavements, 209 (1987).

5) "Laying Handbook for The Vibracoax," The Rmocoax \& CIE, (1982).

6) Amano, T., Moriyoshi, A., Kagami, S., Kasahara, A., Proc. of JSCE, (564), 23 (1997) 


\title{
Summary
}

\section{Analysis of Load Distribution in Asphaltic Mixture Using Dynamic Sensor}

\author{
Akihiko KASAHARA $^{\dagger 1)}$, Takaaki AMANO, and Akihiro MORIYOSHI \\ Faculty of Engineering, Hokkaido University, Nishi 8, Kita 13, Kita-ku, Sapporo 060-0813 \\ ${ }^{\dagger 1)}$ (Present address) North Research Institute, Nippon Hodo Co., Ltd., 76-21 Toiso, Eniwa, Hokkaido 061-1405
}

This paper describes the effects of wheel load and temperature of asphaltic mixture on properties of load distributing characteristics, estimated from relative distributions of vertical stress at bottom of asphaltic mixture and analyzed on basis of wheel tracking test using a dynamic sensor.

Such relative distributions of vertical stress and the effects were compared with those computed by elastic and viscoelastic FEM. By using the same method of analysis, relation between depth of rutting and relative distribution of vertical stress at bottom of asphaltic mixture, was also investigated.

The conclusions obtained follows:

Load distribution by wheel tracking tests were broader than those by FEM. Changes of temperature of asphaltic mixture affected remarkably the load distribution but changes of load had hardly any affects.

\section{Keywords}

Asphalt, Asphaltic mixture, Dynamic sensor, Load distribution, Stress analysis, Finite element method 